\title{
Hemorrhagic adrenal myelolipoma after trauma to left adrenal gland: A case report
}

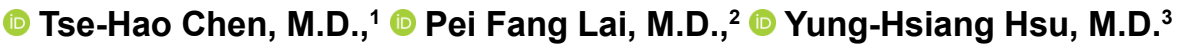

\author{
1Division of Medical Education, Taipei Tzu Chi Hospital, Buddhist Tzu Chi Medical Foundation, New Taipei 231-Taiwan \\ ${ }^{2}$ Department of Emergency Medicine, Buddhist Tzu Chi General Hospital, Buddhist Tzu Chi Medical Foundation, Hualien 970-Taiwan \\ ${ }^{3}$ Department of Pathology, Buddhist Tzu Chi General Hospital, Buddhist Tzu Chi Medical Foundation, Hualien 970-Taiwan
}

\begin{abstract}
Myelolipomas are rare benign tumors comprised of mature adipose tissue and hematopoietic elements.Adrenal myelolipomas associated with traumatic adrenal injury are relatively rare and less common on the left due to the limited size and well-protected position of the gland.A 59-year-old female admitted to the emergency department with intermittent left flank pain radiating to the left abdomen after falling from the bed six hours earlier. Her vital signs were stable, and she had tenderness over the left flank area and left abdomen. Her initial hemoglobin level was $12.9 \mathrm{~g} / \mathrm{dL}$. Bedside focused assessment with sonography for trauma revealed unclear left kidney margins. Contrast abdominal computed tomography (CT) revealed a space-occupying mass, $11.6 \times 10.4 \times 8.8 \mathrm{~cm}$ in dimension, in the left suprarenal region with active bleeding in the lower pole. Angiography did not reveal any active contrast medium extravasation. The CT-guided biopsy, was well performed concomitantly with angiography. Pathological assessment of the biopsy specimen revealed the presence of mostly adipose tissue with few erythrocytes and leukocytes. She was diagnosed with adrenal myelolipoma and admitted to the urology ward for left adrenalectomy with tumor resection. Traumatic adrenal injury, an unusual presentation of adrenal myelolipoma incidentally found in less than $5 \%$ of all abdominal blunt injuries, should be considered in cases of bleeding with trauma to the flank for prompt treatment.
\end{abstract}

Keywords: Adrenal emergency; adrenal myelolipoma; case report; incidentaloma; traumatic adrenal injury.

\section{INTRODUCTION}

The majority of myelolipomas, rare benign tumors comprised mainly of mature adipose tissue and hematopoietic elements, originate from the adrenal gland, although other sites of involvement include retroperitoneum, thorax, and pelvis. ${ }^{[1,2]}$ Adrenal myelolipoma is an incidentaloma typically discovered during routine radiological studies or autopsy. [2] The overall incidence of adrenal myelolipoma is approximately $0.05 \%-0.2 \% .^{[3,4]}$ While most adrenal incidentalomas are nonfunctioning adenomas, tumor-like pheochromocytomas or aldosterone-producing adenomas were also reported.
[4] Importantly, the incidence of adrenal myelolipomas have increased to $15 \%$ of all adrenal incidentalomas with advances in and convenience of computed tomography (CT) and magnetic resonance imaging (MRI). ${ }^{[5,6]}$

Due to their limited size and well-protected position, traumatic injury to the adrenal glands is relatively rare, with the right side affected more frequently. ${ }^{[7,8]}$ The left adrenal gland is spared because of the surrounding organs, whereas the right adrenal gland, which can be compressed by the liver and the vertebral bodies, is more prone to injury. ${ }^{[9]}$ Typically, patients with traumatic injury to the adrenal gland present with non-

Cite this article as: Chen TH, Lai PF, Hsu YH. Hemorrhagic adrenal myelolipoma after trauma to left adrenal gland: A case report. Ulus Travma Acil Cerrahi Derg 2020;26:829-832.

Address for correspondence: Pei Fang Lai, M.D.

Department of Emergency Medicine, Buddhist Tzu Chi General Hospital, No. 707, Section 3 ,

Chung-Yang Road, Hualien 970, Taiwan. 970 Hualien, Taiwan

Tel: 8663856I825 E-mail: Ipf2826@tzuchi.com.tw

Ulus Travma Acil Cerrahi Derg 2020;26(5):829-832 DOI: 10.14744/tjtes.2019.99457 Submitted: 22.1I.2018 Accepted: 06.09.2019 Online: I5.09.2020

Copyright 2020 Turkish Association of Trauma and Emergency Surgery 
specific symptoms, whereas some patients may present with major trauma and nearby organ damage. We herein report an uncommon case of traumatic hemorrhage of the left adrenal myelolipoma presenting to the emergency department.

\section{CASE REPORT}

A 59-year-old female presented to the emergency department with intermittent left flank pain radiating to the left abdomen after falling from the bed six hours earlier. She had a ten-year history of hypertension treated with amlodipine ( 5 $\mathrm{mg} /$ day) and had no history of surgery. The patient first went to a local clinic for pain, which was not resolved.

Physical examination on admission revealed tenderness over the left flank area and left abdomen. Her blood pressure was 130/92 mm Hg with a heart rate of 87 beats per minute. Laboratory test results were as follows: hemoglobin, $12.9 \mathrm{~g} / \mathrm{dL}$; hematocrit, 39.2\%; blood urea nitrogen, $15 \mathrm{mg} / \mathrm{dL}$; creatinine, $0.6 \mathrm{mg} / \mathrm{dL}$; sodium, $14 \mathrm{l} \mathrm{mmol} / \mathrm{L}$; and potassium, $3.6 \mathrm{mmol} / \mathrm{L}$. Her platelet count, prothrombin time, and activated partial thromboplastin time were normal. Bedside focused assessment with sonography for trauma revealed unclear left kidney margins. Contrast abdominal CT due to suspicious left kidney rupture revealed a space-occupying mass, $11.6 \times 10.4 \times 8.8 \mathrm{~cm}$ in dimensions, in the left suprarenal region with active bleeding in the lower pole. The left kidney was encased almost entirely by dense material collection (Fig. I). The liver and spleen were unremarkable. Angiography by a radiologist did not reveal active extravasation, and the renal vein was patent (Fig. 2). The CT-guided biopsy was well performed concomitantly with angiography.

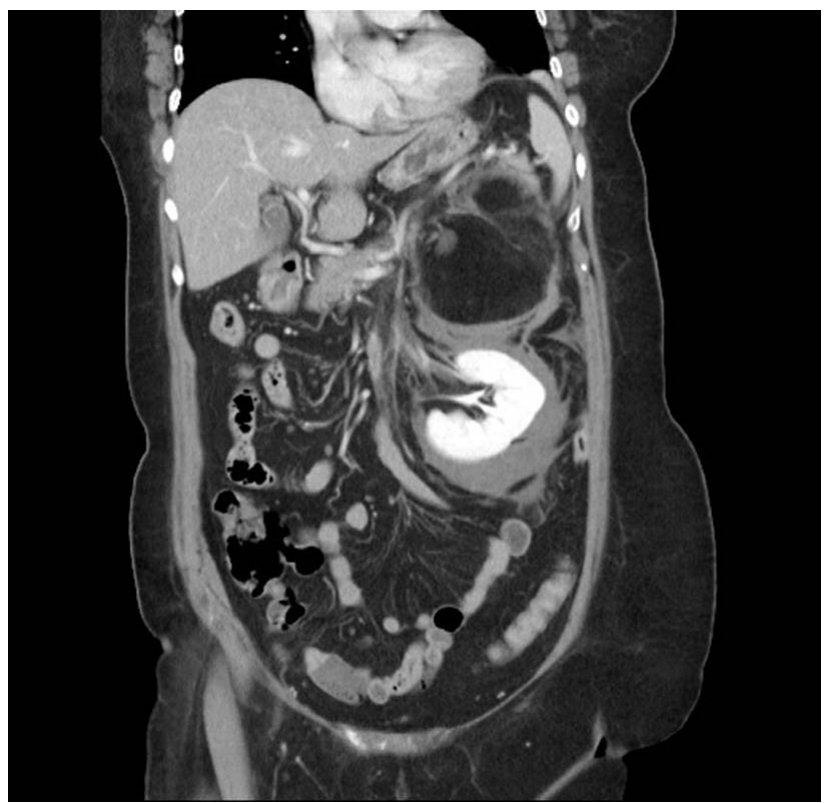

Figure 1. A mass, $11.6 \times 10.4 \times 8.8 \mathrm{~cm}$ in dimensions, in the left suprarenal region. The mass exhibited diffuse soft tissue density composed of macroscopic fat tissue and hematopoietic elements. The dense collection of material in the lower pole of the mass encasing the left kidney was also observed.

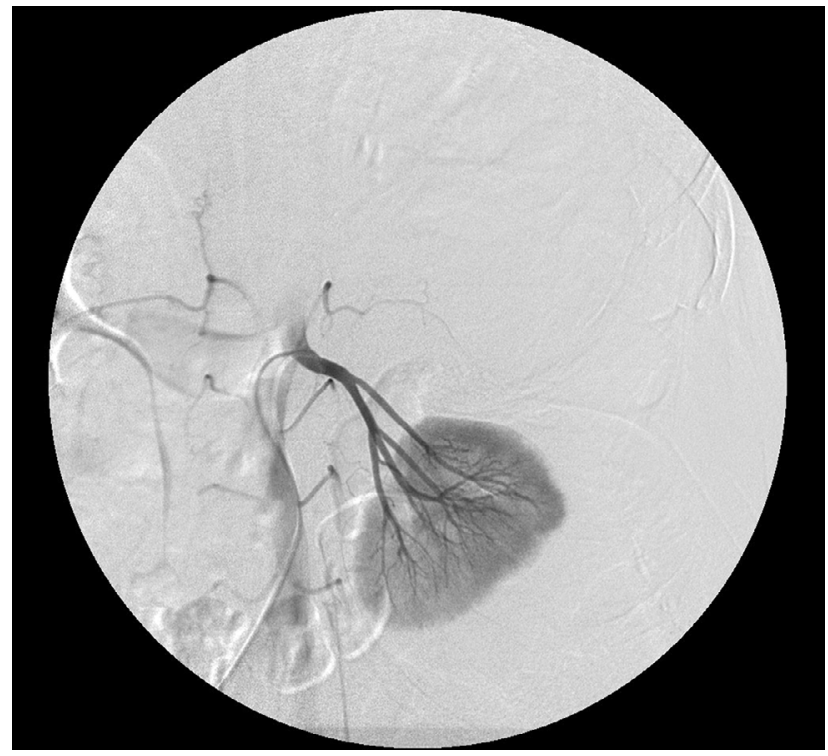

Figure 2. Aortogram and renal angiograms were performed by inserted a 5-Fr angiosheath through the left renal artery. Downward displacement of the left kidney without active contrast medium extravasation was found. Patency of left renal veins was also noted.

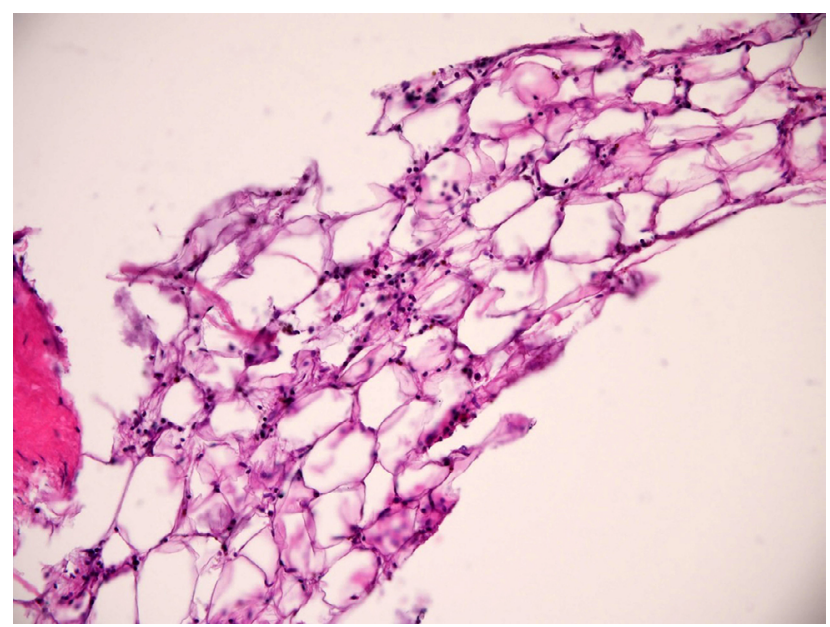

Figure 3. Microscopically, it consisted mostly of adipose tissue with few erythrocytes and leukocytes compatible with adrenal myelolipoma.

Pathological assessment of the biopsy specimen revealed the presence of mostly adipose tissue with few erythrocytes and leukocytes, and the mass was diagnosed as adrenal myelolipoma (Fig. 3). The patient was admitted and underwent left adrenalectomy with tumor resection under the laparotomy method. The procedure was uneventful, and she recovered without sequelae. Patient's consent was obtained for this study.

\section{DISCUSSION}

To our knowledge, the current case of hemorrhage from a massive adrenal myelolipoma due to trauma to the left side is a unique presentation illustrating the relationship between traumatic adrenal injury and adrenal myelolipoma. 
Myelolipoma is a usually small, nonfunctioning benign tumor with nonspecific symptoms, although cases with myelolipomas of up to $35 \mathrm{~cm}$ in diameter were reported. ${ }^{[3,6]}$ Most adrenal myelolipomas are unilateral and on the right side. ${ }^{[6,10]}$ The etiology of myelolipoma remains unclear; however, Zorgdrager et al. ${ }^{[10]}$ suggested that previous high-energy trauma might be a factor. Most patients are asymptomatic, and few experience abdominal discomfort or flank pain. ${ }^{[6,11]}$ However, lethal cases with hemorrhagic shock that arises from giant myelolipomas were described. ${ }^{[3,9,12]}$

Traumatic adrenal injury is rare, comprising less than $5 \%$ of all traumatic injuries. ${ }^{[7,13]} \mathrm{A}$ study reported that the most common mechanism of traumatic adrenal injury was road traffic accidents $(66 \%)$, followed by falling from height $(23.4 \%)$, as in the case of the current patient. ${ }^{[14]}$

Bedside focused assessment with sonography for trauma was utilized in the current case. Active bleeding, albeit echogenic, can be observed as a homogeneous or heterogeneous mass. ${ }^{[7,11]}$ Contrast abdominal CT remains the gold standard for myelolipoma diagnosis. ${ }^{[1,15]}$ The most frequent presentation of traumatic adrenal injury is an oval hematoma encasing the adrenal gland. ${ }^{[7,14,16]}$ Intraparenchymal hematomas and bulky adrenal glands with or without extravasation were also reported. ${ }^{[14]}$ In the current case, extravasation observed by contrast CT was accompanied by a decrease in hemoglobin. However, there were no active bleeding sites by angiography. Several potential events might explain the clinical course. First, angiography might not have detected the contrast extravasation due to venous damage. Second, the large, space-occupying hematoma might have twisted after formation, which would hinder the observation of extravasation by angiography; extravasation due to traumatic adrenal injury was not detected by angiography in $76 \%$ of the cases. ${ }^{[13]}$

There are three treatment options for adrenal myelolipomas: surgical intervention, adrenal artery embolization, and conservative medical treatment. ${ }^{[7]}$ Surgery should be considered for symptomatic cases and tumors larger than $7 \mathrm{~cm} \cdot{ }^{[6,11]}$ Laparoscopic adrenalectomy was conducted increasingly over the years. Giant adrenal myelolipoma with size up to 14 $\mathrm{cm}$ was also reported to be suitable for laparoscopy interventions. ${ }^{\left[{ }^{[7]}\right]}$ Because of its encapsulated structure, conversion from laparoscopic adrenalectomy to open method was unusual. Comparing to open adrenalectomy, laparoscopic adrenalectomy was reported to have less blood loss, shorter hospital stays, sooner recovery and less surgical pain. ${ }^{\left[{ }^{[8]}\right.}$ However, this patient had a large left adrenal myelolipoma with bleeding and hematoma encased left kidney. The laparoscopic method was no recommended at that time. Embolization, a safe approach to stop bleeding, was reported to achieve hemostasis and avoid subsequent adrenalectomy. [19] However, most patients with myelolipoma are treated conservatively. ${ }^{[4-6,10,16]}$
Traumatic adrenal injury is an unusual presentation of adrenal myelolipoma. Although it is incidentally found in less than $5 \%$ of all abdominal blunt injuries, adrenal myelolipoma should be considered in patients presenting with bleeding and a history of trauma to the flank to provide the necessary prompt treatment.

Informed Consent: Written informed consent was obtained from the patient for the publication of the case report and the accompanying images.

Peer-review: Internally peer-reviewed.

\section{REFERENCES}

1. Hakim A, Rozeik C. Adrenal and extra-adrenal myelolipomas - a comparative case report. J Radiol Case Rep 2014;8:1-12. [CrossRef]

2. Schaeffer EM, Kavoussi LR. Adrenal myelolipoma.J Urol 2005;173:1760.

3. Kumar S, Jayant K, Prasad S, Agrawal S, Parma KM, Roat R, et al. Rare adrenal gland emergencies: a case series of giant myelolipoma presenting with massive hemorrhage and abscess. Nephrourol Mon 2015;7:e22671. [CrossRef]

4. Kerkhofs TM, Roumen RM, Demeyere TB, van der Linden AN, Haak HR. Adrenal tumors with unexpected outcome: a review of the literature. Int J Endocrinol 2015;2015:710514. [CrossRef]

5. Shenoy VG, Thota A, Shankar R, Desai MG. Adrenal myelolipoma: Controversies in its management. Indian J Urol 2015;31:94-101.

6. Ramirez M, Misra S. Adrenal myelolipoma: To operate or not? A case report and review of the literature. Int J Surg Case Rep 2014;5:494-6.

7. Aysegul K, Kahraman B, Ozdemir ZM, Görmeli CA, editors. Traumatic adrenal hematoma: clinical and imaging findings. ECR 2016 / C-0193. Austria Center Vienna: European Congress of Radiology; 2016.

8. Tó KJ, Duddalwar VA. Imaging of traumatic adrenal injury. Emerg Radiol 2012;19:499-503. [CrossRef]

9. Chernyak V, Patlas MN, Menias CO, Soto JA, Kielar AZ, Rozenblit $\mathrm{AM}$, et al. Traumatic and non-traumatic adrenal emergencies. Emerg Radiol 2015;22:697-704. [CrossRef]

10. Zorgdrager M, Pol R, van Hemel B, van Ginkel R. Giant adrenal myelolipoma: when trauma and oncology collide. BMJ Case Rep 2014;2014:bcr2014204023. [CrossRef]

11. Daneshmand S, Quek ML. Adrenal myelolipoma: diagnosis and management. Urol J 2006;3:71-4.

12. Fowler AM, Burda JF, Kim SK. Adrenal artery embolization: anatomy, indications, and technical considerations. AJR Am J Roentgenol 2013;201:190-201. [CrossRef]

13. Liao CH, Lin KJ, Fu CY, Wang SY, Yang SJ, Ouyang CH. Adrenal gland trauma: is extravasation an absolute indication for intervention?. World J Surg 2015;39:1312-9. [CrossRef]

14. Panda A, Kumar A, Gamanagatti S, Bhalla AS, Sharma R, Kumar S, et al. Are traumatic bilateral adrenal injuries associated with higher morbidity and mortality?-A prospective observational study. J Trauma Manag Outcomes 2015;9:6. [CrossRef]

15. Mayo-Smith WW, Boland GW, Noto RB, Lee MJ. State-of-the-art adrenal imaging. Radiographics 2001;21:995-1012. [CrossRef]

16. Karwacka IM, Obołończyk $Ł$, Sworczak K. Adrenal hemorrhage: A single center experience and literature review. Adv Clin Exp Med 2018;27:681-7. [CrossRef]

17. Maestroni U, Ziglioli F, Dinale F, Ferretti S, Frattini A, Cortellini P. Is laparoscopy contraindicated in giant adrenal masses?. Surg Laparosc Endosc Percutan Tech 2010;20:288-90. [CrossRef]

18. Thompson GB, Grant CS, van Heerden JA, Schlinkert RT, Young WF $\mathrm{Jr}$, Farley DR, et al. Laparoscopic versus open posterior adrenalectomy: a 
case-control study of 100 patients. Surgery 1997;122:1132-6. [CrossRef]

19. Cody O’Dell M, Liu B, Fursevich D, Contreras FJ. Embolization of spon- taneous hemorrhagic adrenal myelolipoma with variant adrenal arteries. J

Vasc Interv Radiol 2015;26:1086-8. [CrossRef]

\section{OLGU SUNUMU - ÖZET}

\section{Sol adrenal bezde travma sonrası hemorajik adrenal miyelolipom: Olgu sunumu Dr. Tse-Hao Chen, ${ }^{1}$ Dr. Pei Fang Lai, ${ }^{2}$ Dr. Yung-Hsiang Hsu ${ }^{3}$}

${ }^{1}$ Taipei Tzu Chi Hastanesi, Budist Tzu Chi Tıp Vakfı, Tıp Eğitimi Bölümü, Yeni Taipei 231-Tayvan

${ }^{2}$ Budist Tzu Chi Genel Hastanesi, Budist Tzu Chi Tıp Vakfı, Acil Tıp Departmanı, Hualien 970-Tayvan

${ }^{3}$ Budist Tzu Chi Genel Hastanesi, Budist Tzu Chi Tıp Vakfı, Patoloji Bölümü, Hualien 970-Tayvan

Miyelolipomlar, matür yağ dokusu ve hematopoetik elementlerden oluşan nadir iyi huylu tümörlerdir. Travmatik adrenal yaralanma ile ilişkili adrenal miyelolipomlar, bezin sınırlı boyutu ve iyi korunan pozisyonu nedeniyle sol tarafta nispeten nadirdir ve daha az yaygındır. Elli dokuz yaşında kadın hasta, altı saat önce yataktan düştükten sonra sol karın bölgesine yayılan aralıkı sol yan ağrısı şikayeti ile acil servise başvurdu. Vital bulguları stabildi ve sol yan bölgede ve sol karın bölgesinde hassasiyeti mevcuttu. Başlangıç hemoglobin düzeyi $12.9 \mathrm{~g} / \mathrm{dL}$ idi. Travma için ultrason ile yatak başı değerlendirmede sol böbrek sınırları belirsiz olarak saptandı. Kontrastlı abdominal bilgisayarlı tomografide (BT) sol suprarenal bölgede II.6× $0.4 \times 8.8$ $\mathrm{cm}$ boyutunda yer kaplayı bir kitle ile birlikte alt polde aktif kanama saptandı. Anjiyografide herhangi bir aktif kontrast madde ekstravazasyonu saptanmadı. Anjiyografi ile eş zamanlı olarak BT eşliğinde biyopsi başarılı bir şekilde gerçekleştirildi. Biyopsi örneğinin patolojik değerlendirmesi, az sayıda eritrosit ve lökosit içeren çoğunlukla yağ dokusunun varlığını ortaya koymuştur. Hastaya adrenal miyelolipom tanısı konuldu ve tümör rezeksiyonu ile sol adrenalektomi için üroloji servisine yatıııldı. Tüm künt abdominal yaralanmaların \%5'inden azında tesadüfen bulunan adrenal miyelolipomun olağandışı bir sunumu olan travmatik adrenal yaralanma, karın travmasına bağı kanama olgularında acil tedavi için dikkate alınmalıdır. Anahtar sözcükler: Adrenal acil; adrenal myelolipom; insidentaloma; olgu sunumu; travmatik adrenal yaralanma.

Ulus Travma Acil Cerrahi Derg 2020;26(5):829-832 doi: 10.14744/tjtes.2019.99457 